\title{
CABARAN PEKERJA SOSIAL DALAM MENGENDALIKAN PENGURUSAN KES PENDERAAN KANAK-KANAK DI TASKA
}

\author{
NANTHINI RAMALINGAM DAN KHADIJAH ALAVI*
}

Pusat Pengajian Kesejahteraan Manusia dan Masyarakat (PsiTra), Fakulti Sains Sosial dan Kemanusiaan UKM, Bangi

*Corresponding author: khadijah@ukm.edu.my

http://doi.org/10.46754/umtjur.2021.01.011

\begin{abstract}
Abstrak: Peningkatan kes penderaan kanak-kanak sehingga kematian kanak-kanak amat membimbangkan keluarga dan masyarakat. Artikel ini akan membahaskan tentang cabaran pekerja sosial dalam melindungi penderaan kanak-kanak di taska. Kajian lepas amat kurang mengkaji isu penderaan kanak-kanak di taska. Kajian ini dijalankan dengan menggunakan pendekatan kualitatif berpandukan kajian fenomenologi. Teknik pengumpulan data kajian melalui temubual berstruktur secara bertulis. 6 orang informan terdiri daripada pekerja sosial telah dipilih bagi kajian ini dengan menggunakan teknik persampelan bertujuan (purposive sampling). Lokasi kajian yang dipilih ialah taska sekitar Bandar Baru Bangi. Data temubual berstruktur dianalisis secara tematik dan hasil kajian mendapati terdapat tiga cabaran utama iaitu pertama praktis kerja sosial, konflik profesion dan kemahiran dalam mengendalikan pengurusan kes penderaan kanak-kanak. Implikasi kajian ini mencadangkan program kaunseling individu dan kelompok kepada pekerja sosial dan penting meningkatkan latihan dalam kemahiran mengendalikan pengurusan kes penderaan kanak-kanak yang semakin kompleks dan kritikal di masa depan.
\end{abstract}

Kata kunci: cabaran, pengurusan kes, penderaan kanak-kanak, pekerja sosial

\section{THE CHALLENGES OF SOCIAL WORKERS IN DEALING WITH CASE MANAGEMENT AMONG CHILD ABUSE AT TASKA}

\begin{abstract}
The increase in child abuse until the death of children is a concern for families and communities. This article will debate the challenges of social workers in protecting child abuse at child nursery. Previous studies are less likely to examine the issue of child abuse in nurseries. This study was conducted using a qualitative approach based on phenomenology study. Techniques of collecting research data through structured interviews in writing. 6 informants were chosen for this study using purposive sampling technique. The location of the study was selected as a child nursery around Bandar Baru Bangi. Structured interview data was analysed in a thematic manner and the findings found that there were three major challenges, first social practice, profession conflict and lack of skills in case management of child abuses. The implications of this study proposed that individual and group counselling to social worker are important enhance training in the case management to heading more complex and critical cases on child abuse in the future.
\end{abstract}

Keywords : Challenges, case management, child abuse, social worker

\section{Pengenalan}

Berdasarkan statistik Jabatan Kebajikan Masyarakat (JKM), kes penderaan kanakkanak yang dilaporkan kepada JKM bagi tempoh 2012 hingga 2017 adalah sebanyak 22,136 kes. Sebanyak 581 kes penderaan kanak-kanak yang dilakukan oleh pengasuh telah dilaporkan dari tahun 2015 hingga Jun tahun 2016. Menteri Pembangunan Wanita, Keluarga dan Masyarakat Datuk Seri Rohani Abdul Karim berkata bahawa mengikut statistik Jabatan Kebajikan 
Masyarakat (JKM) pula, sebanyak 146 kes mengenai penderaan kanak-kanak oleh pengasuh berlaku seawal tahun 2015 hingga Jun 2016. Sebanyak 32 Taska dikenakan arahan bertulis, 14 Taska dikenakan tindakan kompaun, 4 Taska dikenakan tindakan tutup sementara, 52 Taska telah dimansuhkan pendaftaran dan 2 Taska lagi telah didakwa pada bulan Jun, 2015. Datuk Seri Rohani Abdul Karim berkata bahawa kementeriannya memandang serius mengenai kes penderaan kanak-kanak dan pengabaian yang berlaku di pelbagai tempat termasuk di Taska. Kes penderaan yang dilaporkan berlaku di Ayer Keroh, Melaka pada 11 Ogos 2018 (Mohd Hilme 2018). Kes ini melibatkan dua orang guru kasari kanakkanak yang menampar kanak-kanak sampai jatuh dari kerusi dan video tersebut disebar melalui whatsapp. Satu lagi kes penderaan masih berlaku di Taska yang melibatkan seorang bayi lelaki telah meninggal dunia selepas diambil oleh ibubapa dari Taska Bandar Seri Botani, Ipoh pada 9 Mac 2019 (Farah Suhaidah 2019). Bayi lima bulan meninggal dunia di Taska pada 17 Januari 2020 dimana ibu baru seminggu hantar ke taska berkenaan untuk penjagaan bayi. Pengasuh hanya perasan bayi tersebut tidur terlangkup dan didapati telah meninggal dunia (Fareez Azman, 2020).

Faktor utama terjadinya kes penderaan kanak-kanak di taska adalah disebabkan oleh taska tidak berdaftar dan jumlah kanak-kanak yang dijaga terlalu ramai. Hampir kesemua taska tidak berdaftar tidak mengikuti kursus atau latihan yang dianjurkan oleh Jabatan Kebajikan Masyarakat (JKM, Kementerian Pembangunan Wanita, Keluarga dan Masyarakat bagi meningkat kualiti penyediaan perkhidmatan di Taska. Antara kandungan kursus JKM ialah pendedahan psikologi kanak-kanak, kuota atau nisbah yang dianjurkan mengikut luas kaki persegi sesuatu permis pusat taska, persekitaran yang selesa menjaga bayi atau kanak-kanak dan menu makanan serta keselamatan persekitaran taska tersebut. Menurut Zaida Mustafa (2017) kebanyakan ibu bapa mengambil jalan mudah dengan menghantar anak mereka ke taska yang tidak berdaftar atau rumah pengasuh dalam kejiranan mereka. Apabila berlaku kes kematian tersedak susu, didera oleh pengasuh dan pelaporan ke pihak media; maka baru lah ibu bapa sedar bahawa taska tersebut tidak berdaftar. Banyak isu yang perlu diambil kira oleh ibu bapa sebelum hantar anak mereka ke taska berkaitan keselamatan kanak-kanak (Leong, 1997; Santrok, 2007); kelayakan pengasuh dan yuran mengikut kemampuan ibu bapa ((Leong, 1997; Noble, 2007; Rozilawati, 2003); piawai kualiti pusat penjagaan kanak-kanak yang dipersetujui di peringkat kebangsaan dan antarabangsa adalah faktor keselamatan, pemakanan, kurikulum, penguatkuasaan, pendidik, pengasuhan, komunikasi dan kesihatan (Bechtold, 2011). Pada pendapat pengkaji sehingga kini Malaysia belum memikirkan tentang SOP suntikan daan immunisasi pengusaha, pegasuh, pekerja pembersihan serta penyedia makanan di taska berdaftar atau tidak berdaftar. Hampir $60 \%$ bayi dan kanak-kanak terdedah kepada salah satu atau dua jenis penderaan dan pengabaian (Finkelhor et al. 2009). Pengkaji mendapati kajian mengenai kes penderaan kanak-kanak adalah amat penting kerana memberi implikasi kepada trauma kanak-kanak tersebut apabila dewasa. Latihan kemahiran dalam kalangan pekerja sosial yang mengendalikan kes penderaan kanak-kanak juga perlu diambil kira dalam meningkatkan kesejahteraan keluarga mangsa penderaan kanak-kanak. Kesan trauma boleh menyebabkan seseorang merasakan tidak selamat dan sering dihantui perasaan takut, seram dan tidak berdaya. Kesemua kesan ini memberikan kesan kepada kefungsian psikososial kanak-kanak tersebut dalam jangkamasa panjang untuk menjalani kehidupan harian yang sejahtera (Siegel 2015). 


\section{Tinjauan Literatur}

Pekerja sosial ialah profesion membantu golongan berkeperluan bagi meningkatkan kefungsian sosial dan berperanan sebagai penghubung, menjadi orang tengah dan perunding untuk kanak-anak dan keluarga mereka (Brahim 2017). Secara operasional dalam artikel ini merujuk kepada pekerja sosial adalah kemahiran pengurus kes kanak-kanak. Summers (2012) mendefinisikan pengurusan kes sebagai satu proses penilaian terhadap keseluruhan situasi klien dan menyelesaikan masalah dan keperluan berdasarkan penilaian. Manakala Woodside \& McClam (2006) menggariskan proses pengurusan kes kepada tiga elemen penting iaitu proses pengurusan kes (peringkat pentaksiran, perancangan dan pelaksanaan), rol dan model. Pekerja sosial menghadapi masalah dan cabaran dalam menyelesaikan kes penderaan kanakkanak di Taska. Pengurus kes yang terdiri daripada pekerja sosial belum bersedia bersedia untuk menangani masalahmasalah kompleks penderaan kanak-kanak dan pengabaian (Johansen 2002). Pekerja sosial tidak kira pegawai pelindung atau pegawai akhlak perlu mempunyai tahap persediaan yang lengkap dan mempunyai kemahiran dalam ilmu perundangan dalam pengendalian kes yang berkaitan dengan kanak-kanak. Pengetahuan dan kemahiran pengurusan kes yang merangkumi perundangan, kemampuan bekerja dalam satu pasukan dan berkolaborasi dengan pelbagai agensi merupakan satu cabaran kepada pekerja sosial. Kerjasama pelbagai agensi merupakan persekitaran kerja penting bagi pekerja sosial yang berkhidmat dengan perlindungan kanakkanak. Cabaran seterusnya yang dihadapi oleh pekerja sosial kebajikan kanak-kanak ialah konflik profesion dengan keselamatan diri (Salina \& Jill 2011). Dalam kajian mereka juga telah mengenal pasti salah satu kerisauan pekerja sosial kanak-kanak ialah keselamatan diri semasa bekerja di lapangan. Pekerja sosial merasakan keselamatan mereka terancam dan berisiko berbanding dengan rakan mereka iaitu polis yang mempunyai senjata. Keadaan ini akan menjejaskan proses mendapatkan maklumat dan menyebabkan laporan yang disediakan tidak dapat disediakan secara holistik

Kajian lepas dirumuskan bahawa cabaran pekerja sosial dalam pengurusan kes kanak-kanak terbahagi kepada lima permasalahan utama (Brahim, S. 2017). Pertama, kelemahan dalam kemahiran praktis di mana pekerja sosial lebih tertumpu kepada mangsa/klien mengikut akta kanakkanak berbanding pengurusan kes tersebut. Pekerja kes kanak-kanak mempunyai autoriti dalam mengendalikan kes kanakkanak melalui pewartaan sebagai Pelindung di bawah Seksyen 8 dan pelantikan pegawai akhlak di bawah seksyen 10 Akta KanakKanak 2001 (Malaysia, 2005). Pelindung berperanan menyelamat dan melindungi kanak-kanak dengan menempatkan kanakkanak di tempat selamat atau dengan orang yang layak dan sesuai (Rahimah \& Suriati, 2013; Tengku Fatimah Muliana \& Engku Ahmad Zaki, 2012; Nor Shafrin \& Rohani 2010; Lukman 2009) berbanding pekerja sosial yang mengendalikan kes kanakkanak. Kedua ialah kompetensi praktis pekerja sosial kanak-kanak tidak jelas. Pada suatu ketika tahap profesionalisme pekerja sosial dipersoalkan oleh klien (Salina $\&$ Jill 2011). Ketiga ialah isu 'burnout' dalam kalangan pekerja sosial kanakkanak di JKM yang belum dikaji secara empirikal. Keempat ialah isu pentadbiran dan pengurusan kes yang dikaitkan tentang hubungan terapeutik pekerja sosial dengan kanak-kanak di mana dilema pengurus kes lebih memberi tumpuan kepada pengurusan kes berbanding berfokus klien (Client Centred) (Aronson \& Smith 2011). Kelima berkaitan latihan dan penyeliaan dalam pengurusan kes masih kurang memuaskan yang menyebabkan kebanyakan kes penderaan kanak-kanak gagal dibawa ke mahkamah untuk menjatuhkan hukuman kepada mangsa (Salina \& Jill 2011). Dalam 
praktis perkhidmatan kanak-kanak, pekerja sosial kanak-kanak perlu memahami dan mengetahui tentang sistem pengurusan kes (Garrison, 2003). Menurut Summers (2012), beliau mendefinisikan pengurusan kes sebagai satu proses penilaian terhadap keseluruhan situasi klien dengan menyelesaikan masalah dan keperluan klien berdasarkan penilaian. Manakala, (Woodside \& Mcclam, 2012) menggariskan proses pengurusan kes kepada 3 elemen penting iaitu melalui peringkat pentaksiran, perancangan dan perlaksanaan model yang sesuai dalam kalangan kanak-kanak yang mengalami penderaan.

Ahli-ahli psikologi seperti Bloom (1964) dan Spodek \& Davis (1982) berpendapat bahawa perkembangan awal kanak-kanak amat penting pada peringkat prasekolah kerana peringkat ini merupakan landasan dan akar umbi kepada peringkat permulaan. Justeru itu, sewajarnya ibu bapa perlu peka dalam pemilihan sesebuah pusat asuhan. Hal ini kerana, institusi yang mampu menyediakan perkhidmatan dan keperluan sosial yang baik dapat mewujudkan keseimbangan pembentukan sahsiah serta keperibadian diri kanakkanak tersebut. Jabatan kebajikan Malaysia telah mengadakan beberapa program bagi mencegah berlakunya penderaan kanak-kanak. Menurut Khadijah \& Fadhil (2008) sistem pencegahan pada masa kini, lebih berbentuk hukuman penjara dan penalti kepada pelaku penderaan. Program kaunseling dan psikoterapi ke atas pelaku penderaan yang menjalani hukuman penjara juga adalah sangat penting. Programprogram seperti kelas motivasi, seminar, forum, dan Pendidikan keibubapaan juga perlu diberi kepada pelaku penderaan kanak-kanak. Program sebegini dapat mengurangkan insiden penderaan kanakkanak dan menghindarkan pelaku serta mangsa dari peralihan sikap mendera. Menurut Tallman (2000) mendapati bahawa ibu bapa atau penjaga perlu mengambil tanggungjawab atau peka dalam memilih pusat jagaan yang berdaftar dan mencapai standar operasi yang berkualiti sebelum menghantar anak-anak mereka.

Kajian lepas lebih banyak mefokuskan penderaan yang berlaku di rumah dan pendera juga merupakan ibu bapa kandung kepada kanak-kanak tersebut. Manakala kajian ini lebih ini menumpukan kepada penderaan kanak-kanak di taska dan pelaku terdiri daripada pengusaha dan pengasuh di Taska. Jurang kajian kedua yang dikenal ialah kurang penyelidikan dan penerbitan yang dijalankan berkaitan dengan cabaran pekerja sosial dalam mengendalikan pengurusan kes berkaitan dengan penderaan kanak-kanak di Malaysia. Kajian cabaran pekerja sosial yang mengendalikan kes pengurusan berkaitan dengan penderaan kanak-kanak amat penting dijalankan kerana ianya memberi implikasi kritikal kepada pertumbuhan kanak-kanak tersebut.

\section{OBJEKTIF KAJIAN}

Secara umumnya, kajian ini bertujuan untuk meneroka cabaran yang dihadapi oleh pekerja sosial dalam mengendalikan kes penderaan kanak-kanak di Taska.

\section{METODOLOGI KAJIAN}

Pendekatan kajian mengenai penderaan kanak-kanak di Taska ialah berbentuk kualitatif iaitu berpandukan kajian fenomenologi yang menghuraikan pengalaman manusia melalui dengan objek dan peristiwa yang berada dalam diri mereka dan tidak dapat dilihat dalam gejala yang kita dapat menangkap dengan deria. Kajian ini dijalankan di Selangor iaitu di Taska di Seksyen 15, Bangi. Pemilihan lokasi tersebut disebabkan pernah berlaku penderaan kanak-kanak oleh pengasuh di Taska tersebut. Pekerja sosial dan pengusaha taska terlibat dalam kajian ini. Temu bual mendalam (in-depth interview) di dalam kajian kualitatif ini dilaksanakan secara terbuka dan separa berstruktur. 
Teknik persampelan yang digunakan ialah persampelan secara bertujuan (purposive sampling) iaitu sudah ditetapkan matlamat pemilihan informan tersebut yang melibatkan justifikasi tertentu dalam memilih informan kajian. Persampelan kajian terdiri daripada tiga kumpulan informan yang telah dipilih. Seramai 6 orang pekerja sosial dipilih oleh pengkaji untuk ditemu bual secara lebih mendalam dan tidak berstruktur. Pengkaji menemubual 6 informan untuk mendapatkan maklumat tentang cabaran pekerja sosial dalam mengendalikan kes penderaan kanak-kanak di Taska. Mereka juga telah ditemubual tentang faktor berlaku penderaan di taska dan bagaimana mereka melaporkan kes penderaan kanak-kanak jika berlaku di taska. Sesi temubual dijalankan dalam masa 45 minit hingga 90 minit. Traskripsi verbatim dilakukan dalam tempoh 24 jam sebelum dianalisis. Sesi temu bual dengan informan akan berlangsung lagi sehingga data mencapai tahap tepu. Analisis secara manual digunakan dalam kajian ini.

Data telah dianalisis secara tematik dan hasil temubual bertulis informan membantu pengkaji meneroka isu atau masalah yang dihadapi oleh mereka ketika pekerja sosial menghadapi cabaran dalam mengendalikan kes penderaan kanakkanak di Taska. Matlamat analisis tematik adalah untuk mengenal pasti setiap objektif dan menganalisis data yang penting dan bermakna serta mengunakan tema tersebut sebagai suatu yang mampu menjelaskan isu yang ingin dikaji. Data yang telah dikoding disusun ke dalam open coding, selective coding dan axial coding yang lebih specifik yang seolah-olah menunjukkan sesuatu yang spesifik. Lazimnya kebanyakan tema adalah deskriptif dan menggambarkan corak tema yang muncul penting dan menarik disajikan sebagai hasil kajian. Lazimnya kebanyakan tema adalah deskriptif dan menggambarkan corak data yang relevan dengan tema kajian.

\section{DAPATAN DAN PERBINCANGAN}

\section{Latar Belakang Informan}

Demografi informan diterangkan mengikut jantina, umur, bangsa/agama, status perkahwinan, taraf pendidikan dan pekerjaan. Jadual 1 menunjukkan bahawa dari segi jantina, menunjukkan perbezaan ketara dalam kajian ini di mana terdapat satu informan adalah lelaki iaitu informan P1 dan yang lain iaitu informan P2 hingga P12 adalah perempuan. Dari segi bangsa pula, bangsa India merupakan seorang informan sahaja iaitu P2 dan selainnya adalah berbangsa Melayu. Dari segi anutan agama, informan beragama Islam ialah seramai 11 orang dan hanya seorang informan sahaja beragama Hindu. Dari segi tahap pendidikan, terdapat lima orang informan berpendidikan tinggi, Ijazah Sarjana Muda iaitu informan P1, P2, P4, P5 dan P6. Seorang informan berpendidikan tahap diploma iaitu informan P3.

Jadual 1: Latar Belakang Demografi Pekerja Sosial

\begin{tabular}{ccccccc}
\hline Informan & $\begin{array}{c}\text { Jantina } \\
\text { L/P }\end{array}$ & Umur & $\begin{array}{c}\text { Bangsa/ } \\
\text { Agama }\end{array}$ & $\begin{array}{c}\text { Status } \\
\text { Perkahwinan }\end{array}$ & $\begin{array}{c}\text { Taraf } \\
\text { Pendidikan }\end{array}$ & Pekerjaan \\
\hline P1 & L & 55 & $\begin{array}{c}\text { Melayu/ } \\
\text { Islam }\end{array}$ & Berkahwin & $\begin{array}{c}\text { Ijazah Sarjana } \\
\text { Muda Kerja } \\
\text { Sosial }\end{array}$ & $\begin{array}{c}\text { Pekerja } \\
\text { Sosial }\end{array}$ \\
\hline P2 & P & 38 & $\begin{array}{c}\text { India/ } \\
\text { Hindu }\end{array}$ & Berkahwin & $\begin{array}{c}\text { Sjazah } \\
\text { Sembang Muda } \\
\text { Piri }\end{array}$ & $\begin{array}{c}\text { Pekerja } \\
\text { Sosial }\end{array}$ \\
\hline
\end{tabular}




\begin{tabular}{ccccccl}
\hline P3 & P & 34 & $\begin{array}{c}\text { Melayu/ } \\
\text { Islam }\end{array}$ & Berkahwin & Diploma & $\begin{array}{l}\text { Pekerja } \\
\text { Sosial }\end{array}$ \\
\hline P4 & P & 41 & $\begin{array}{c}\text { Melayu/ } \\
\text { Islam }\end{array}$ & Berkahwin & $\begin{array}{c}\text { Ijazah Sarjana } \\
\text { Muda Antropologi }\end{array}$ & $\begin{array}{l}\text { Pekerja } \\
\text { Sosial }\end{array}$ \\
\hline P5 & P & 38 & $\begin{array}{c}\text { Melayu/ } \\
\text { Islam }\end{array}$ & Berkahwin & $\begin{array}{c}\text { Ijazah Sarjana } \\
\text { Muda Sains } \\
\text { Politik }\end{array}$ & $\begin{array}{l}\text { Pekerja } \\
\text { Sosial }\end{array}$ \\
\hline P6 & P & 39 & $\begin{array}{c}\text { Melayu/ } \\
\text { Islam }\end{array}$ & Berkahwin & $\begin{array}{c}\text { Ijazah Sarjana } \\
\text { Muda Linguistik }\end{array}$ & $\begin{array}{l}\text { Pekerja } \\
\text { Sosial }\end{array}$ \\
\hline
\end{tabular}

\section{Cabaran Menangani Isu Penderaan}

Analisis tematik dalam kajian ini mendapati cabaran pekerja sosial dalam mengendalikan kes pengurusan penderaan kanak-kanak didapati tema praktis kerja sosial, konflik profesion dan kemahiran dalam mengendalikan pengurusan kes.

\section{i. Praktis Kerja Sosial}

Praktis atau amalan kerja sosial terdiri daripada aplikasi profesional, nilai, prinsip dan teknik kerja sosial untuk mencapai matlamat dalam membantu klien mendapatkan perkhidmatan tangible, kaunseling dan psikoterapi kepada individu, kumpulan dan komuniti melalui penyediaan perkhidamatan sosial, kesihatan, kewangan dan proses perundangan (NASW 2005). Dalam praktis perkhidmatan kanak-kanak, pekerja sosial kanak-kanak perlu memahami dan mengetahui tentang sistem pengurusan kes (Garrison, 2003). Summers 2012, mendefinisikan pengurusan kes sebagai satu proses penialaian terhadap keseluruhan situasi klien dan menyelesaikan masalah serta keperluan berdasarkan penilaian. Berdasarkan analisis tema kajian kualitatif dibentuk, informan P1 dan P6 menyokong dan memberi penjelasan bagi tema ini. Antara kenyataan yang dipetik dalam tema ini

“pekerja sosial perlu buat praktis sebelum menjalankan sesuatu kes...saya selalu bahagikan tugas seperti masa untuk melawat klien... penempatan yang sesuai untuk klien... semasa membuat assessment (home visit) perlu mengatasi halangan...saya sentiasa merangka satu case plan untuk klien..." (Informan P1, Pekerja Sosial, Lelaki, Melayu)

Menurut informan P1, beliau peka dengan tugas dan memahami prosidur pelaksanaan praktis kerja sosial dan teknik dalam pengurusan kes penderaan kanak-kanak. Prinsip dan kode etika yang perlu dipatuhi ialah a) penerimaan dan memahami mengenai keperluan dan perasaan klien; b) tidak berprasangka buruk terhadap klien; c) tidak menghukum dan sentiasa berandaian setiap klien adalah unik; d) memberi kebebasan kepada klien untuk mengemukakan permasalahan mereka; e) tidak mementingkan diri sendiri dalam menjalankan praktis kerja sosial; f) mengawal emosi dan bersikap objektif melalui bersikap empati terhadap klien dan g) menjaga kerahsiaan berkaitan identiti klien dan mencatatkan kes dengan melalukan rancangan kes yang berkesan. Namun kadangkala untuk mengekalkan prinsip dan etika agak sukar dikawal kerana kes penderaan kanak-kanak melibatkan emosi dan perasaan marah, misalnya "bagaimana boleh membiarkan suami pengasuh boleh merogol bayi sehingga mati" dan mengapa sanggup "meletakkan bayi dalam peti sejuk". Pengkaji juga sedar bahawa bukan mudah untuk berkomunikasi dengan klien yang mempunyai masalah. 


\section{ii. Konflik Profesion}

Secara umumnya kerja sosial merupakan bidang profesion yang menumpukan kepada perkhidmatan manusia dalam mempertingkatkan kesejahteraan dan kualiti hidup (Saparin, 2014). Aspek kesejahteraan sosial di sini merujuk kepada dasardasar yang berkaitan dengan kesihatan, pendidikan, perumahan, dan pembangunan komuniti, atau lebih spesifik lagi sebagai perkhidmatan sosial (Syamsuddin \& Azlinda, 2012). Daripada dua definisi tersebut, dapat disimpulkan bahawa kerja sosial adalah sebuah perkhidmatan yang membolehkan setiap individu berfungsi dengan baik di dalam masyarakat, pekerjaan, pergaulan, dan membantu serta melindungi masyarakat mengatasi segala permasalahan kesan daripada interaksi sosial yang kompleks Muhd Dhamir \& Samir 2019). Tema seterusnya ini merujuk kepada informan P2, P4 dan P8 yang ditemu bual dalam kajian ini. Konflik profesion sering berlaku di semua tempat kerja tanpa mengira pangkat yang dimiliki. Perkara ini sekaligus menyebabkan berlakunya perselisihan faham antara satu sama lain. Ini kerana, seseorang itu akan jadi tertekan jika ingin melakukan sesuatu kerja dengan sempurna. Hal ini dapat membuktikkan bahawa mesti akan berlaku konflik profesion jika seseorang itu tidak bekerjasama dan berkongsi tugasan yang diberi.

“saya juga kadang kala akan keliru dengan profesion...sebab sering kali sukar untuk mengelak masalah... nilai personal akan jadi lebih dari nilai professional...saya sentiasa tabah menghadapi cabaran...dalam profesion sebagai pegawai saya harus bertanding dengan collague yang lain..." (Informan P2, Pekerja Sosial Perempuan, India)

Berdasarkan temu bual informan P2 bersama pengkaji menunjukkan bahawa informan berasa keliru dengan kerja yang dilakukan olehnya. Walaupun beliau sering berusaha untuk yang terbaik, tetap akan ada kekurangan dalam kerjanya. Kadang kala, informan pernah dipandang rendah oleh rakan sekerjanya. Namun, informan 2 iaitu dikenali sebagai pegawai pekerja sosial tidak pernah berputus asa dan sentiasa melakukan profesion dengan jujur dan ikhlas.

"saya rasa polis juga boleh bantu jika menerima aduan...bukan kerja pelindung sahaja untuk menjaga mangsa yang terbabit...saya pernah perasan perkara ini dalam kebanyakkan jadian... pihak berkepentingan sentiasa tidak melakukan tugasan dengan cara yang sepatutnya...saya lihat perkara ini dari segi peruntukkan undangundang yang dibekalkan..." (Informan P4, Pegawai Kebajikan, Perempuan, Melayu)

Berdasarkan pernyataan informan P4, menunjukkan bahawa mereka juga pernah mengalami konflik profesion dalam isu pekerjaan. Informan P4 mengatakan pihak polis juga boleh mengendalikan beberapa kes yang sepatutnya. Pengalaman lalu dalam mengendalikan kes memberi informan kemahiran dalam mengendalikan kes pengurusan penderaan kanak-kanak. Pekerja sosial juga perlu mendapatkan khidmat bantuan daripada polis dan doktor perubatan dalam mengendalikan kes dengan baik. Pekerja sosial perlu mendapatkan kaunseling atau terapi supaya profesi mereka tidak terganggu dan sentiasa melakukan refleksi diri bagi mengurangkan tekanan atau burnout dalam mengendalikan kes penderaan kanak-kanak.

\section{iii. Kemahiran Menangani Pengurusan Kes Penderaan}

Hasil kajian mendapati bahawa tema cabaran pekerja sosial daripada aspek kemahiran dalam mengurus kes penderaan kanak-kanak adalah salah satu perkara penting bagi membantu kanak-kanak dan 
ibu bapa mereka. Jika seseorang itu tidak mempunyai kemahiran, maka mereka tidak dapat memberi hasil kerja yang memuaskan dalam menangani sesuatu permasalahan. Kemahiran itu mudah dipelajari jika seseorang mempunyai minat yang mendalam dalam bidang tugas yang dijalan. Berikut merupakan pernyataan daripada informan kajian melalui temu bual yang dijalankan:

"saya selalu meningkatkan kemahiran kerja saya...bukan mudah untuk deal dengan klien yang bermasalah ni...saya sebagai pegawai perlu menguruskan pelbagai kes yang diberi...kemahiran tu penting untuk menjalankan tugas... saya juga mewujudkan hubungan yang baik dengan agensi yang lain..." (Informan P5, Pekerja Sosial, Perempuan, Melayu)

Berdasarkan kata-kata Informan P5 tersebut jelas membuktikan bahawa dirinya mengharapkan perubahan dalm kemahiran yang dimiliki. Informan P5 menjelaskan bukan senang untuk melayan klien yang mempunyai masalah. Untuk melahirkan rasa kepercayaan dari klien, pegawai berkenaan perlu meningkatkan kemahiran dalam bidang yang diambil. Kemahiran penting ialah mengurangkan rasa trauma dalam kalangan ibu bapa dan kanak-kanak semasa mengendalikan pemeriksaan atau temubual dengan klien. Pekerja sosial juga perlu memastikan pegawai yang terlibat dalam kes penderaan kanak-kanak harus kompeten dan profesional. Suasana pemeriksaan perlu dalam keadaan yang aman dan tenteram tanpa mencetuskan persekitaran yang menggangu perasaan dan emosi klien dan mangsa. Pengaturan waktu dengan pihak media juga perlu dikendalikan dengan baik kerana boleh mencetuskan kontrovesi kepada klien dan pekerja sosial. Pekerja sosial juga perlu mengendalikan kes konference dengan pelbagai agensi bagi memastikan penilaian dan rehabilitasi kanak-kanak serta penjaga mereka dapat kesejahteraan dan pembelaan yang baik.

\section{RUMUSAN DAN CADANGAN}

Cabaran pekerja sosial menemui maklumat untuk menangani isu penderaan kanakkanak di Taska berdasarkan keperluan objektif yang ingin dicapai. Cabaran yang telah dikemukakan oleh pekerja sosial dalam mengendalikan kes pengurusan penderaan kanak-kanak ialah praktis kerja sosial, konflik profesion dan kemahiran dalam mengendalikan kes. Pekerja sosial yang telah menjadi informan dalam kajian ini mengatakan bahawa bukan mudah untuk melakukan proses pemeriksaan dan penilaian terhadap kanak-kanak dan ibu bapa mereka dalam menghadapi trauma. Pekerja sosial sentiasa memastikan keselamatan dan kesejahteraan kanak-kanak sebagai risiko utama dalam pengurusan kes. Pekerja sosial juga boleh mencapai tahap burnout dalam mengendalikan pengurusan kes penderaan kanak-kanak. Maka JKM perlu memastikan pekerja sosial mendapat peluang untuk merefleksi diri, motivasi, intervensi, latihan mempertikatkan kemahiran, praktis supaya perkhidmatan yang diberikan lebih efektif dan efisien. Peluang ini adalah untuk pekerja sosial tidak terganggu emosi semasa menjalankan pemeriksaan, penilaian dan pelaporan kes pengurusan penderaan kanak-kanak di Taska. Komunikasi berkesan antara pekerja sosial dengan pelbagai agensi (polis, pegawai perubatan dan pihak bekepentingan lain) dapat membantu menjayakan kes pengurusan penderaan kanak-kanak dengan lebih berkesan.

Dasar Perlindungan Kanak-Kanak ini merupakan satu dasar yang mengandungi pernyataan mengenai prinsip perlindungan kanak-kanak selaras dengan Konvensyen Mengenai Hak Kanak-kanak (CRC) dan Akta Kanak-Kanak 2001. Dasar ini memberi tumpuan kepada aspek advokasi, pencegahan, khidmat sokongan dan penyelidikan dan pembangunan bagi melindungi kanak-kanak. Secara khususnya, Dasar Perlindungan Kanak- 
Kanak bertujuan untuk memastikan setiap kanak-kanak mendapat perlindungan daripada pengabaian, penderaan, keganasan dan eksploitasi. Dasar ini juga menjadi pemangkin kepada kesedaran dan komitmen semua pihak, termasuk setiap anggota masyarakat dalam melindungi kanak-kanak.

Pengkaji juga mencadangkan kajian akan datang mengambilkira tentang trauma yang dialami oleh kanak-kanak sebagai mangsa penderaan kanak-kanak dan ibu bapa mereka. Penggunaan reka bentuk kajian jangka panjang (longitudinal study) dan pendekatan kerja sosial sekolah dalam memahami dan aplikasi intervensi bagi mengatasi trauma dalam kalangan kanakkanak taska yang melalui pengalaman penderaan di peringkat sekolah rendah, menengah dan universiti. Proses pemulihan mengambilmasa yang lama dan unik kepada setiap individu mangsa penderaan. Ianya merupakan satu tugas yang sangat mencabar kepada pekerja sosial untuk praktis kerja sosial bagi menangani isu trauma dalam kalangan kanak-kanak di Malaysia dalam membina modal insan negara yang cemerlang dan menjadikan Malaysia negara maju.

\section{PENGHARGAAN}

Kajian ini telah dibiayai sepenuhnya oleh pelajar prasiswazah Program Kerja Sosial, Fakulti Sains Sosial dan Kemanusiaan, Universiti Kebangsaan Malaysia. Ucapan penghargaan ditujukan kepada pensyarah, ibu bapa dan rakan-rakan yang telah terlibat dalam menjayakan kajian ini.

\section{RUJUKAN}

Alavi, K. Aizan Sofia Amin, Subhi, N, Mohamad, M. S. \& Sarnon, N. 2012. Kerja sosial di sekolah: memahami dan menangani penderaan kanak-kanak. Jurnal e-bangi, jilid 7, bilangan 1, Ms 17-37.
Anon. 2017, 4,652 kes penderaan libatkan kanak-kanak dlm. utusan malaysia. 17 Mac, 2017,http://www.utusan. com.my/berita/parlimen/4-652kespenderaanlibatkan- kanak- kanak1.458091\#navallsections.

Aronson, J., \& Smith, K. 2011. Identity work and critical social service management: Balancing on atightrope?. British Journal of Social Work, 41(3), 432448.

Bechtold, Joy Marie. 2011. Early-Care and Education Teachers' Perception of High Quality Early-Care and Education Programming in Relation to Their Educational Attainment Level and Experience, ProQuest LLC, Ph.D. Dissertation, The Pennsylvania State University.

Brahim, S. 2017. Praktis Kerja Sosial Dalam Pengurusan Kes Kanak-Kanak: Kajian Di Jabatan

Kebajikan Masyarakat. Research Colloqium at Intan Bukit Kiara, Kuala Lumpur.

Bloom, Benjamin S. Stability and Change in Human Characteristics. New York: John Wiley and Sons, Inc., 1964.

Siegel, D. 2015. Trauma-informed school social work. Social Work Today. Vol. 15 (5): 16

Farah Subahidah Othman. 2019. Bayi 4 bulan meninggal dunia di taska. Berita Harian 9 Mac 2019.

Fareez Azman. 2020. Rupanya itu petanda dia hendak pergi - ibu bayi 5 bulan meninggal dunia di taska. Berita Astro Awani. 17 Januari 2020.

Finkelhor, D., Turner, H. A., Ormrod, R. K., \& Hamby, S. L. (2009). Violence, abuse, and crime exposure in a national sample of children and youth. Pediatrics, 124(5): 1411-1423. 
Garrison, J. M. 2003. Child welfare professionals' perceptions of competencies needed in

child welfare practice in northern Minnesota.(3102094Ed.D.),University of Minnesota, Ann Arbor. Retrieved from http://search.proquest.com/ docview $/ 305330811$ ? accountid $=41453$ ProQuest Dissertations \& Theses Global database.

Hilme Hussin. 2018. Guru tadika didakwa dera budak. Berita Harian 20 Ogos 2018.

Jal Zabdi Mohd Yusuff, Siti Hajar Abu Bakar Ah \& Weatherley, R. 2008. International trends in child abuse prevention and risk assessment: Implications for Malaysia. Malaysian Journal of Social Administration, 5, 2150. J.R Spencer, "Children"s evidence: The barker case and the cased for pigot" dlm. archbold review 3, 5-8, 2010.

Johansen, P. S. (2002). Key competencies in public-child welfare: A comparison of the priorities of social-work faculty and public-child-welfare supervisors. (3049684 Ed.D.), University of San Francisco, Ann Arbor. Retrieved from http://search.proquest.com docview/305481196? accountid=4 1453. Pro-Quest Dissertations \& Theses Full Text database

Leong, J. 1997. Parent choice of early childhood education and care services. Australian Journal of Early Childhood. Vol. 32 (2): 51-57.

Lukman Z.M. 2009. Childhood abuse among children involved in prostitution in Malaysia. The Social Sciences. 4 (567572).

Kasmini Kassim. 1998. Penderaan emosi kanak-kanak: trauma terselindung. Bangi: Penerbitan Universiti Kebangsaan Malaysia
Khadijah Alavi \& Mohamed Fadzil Che Din. 2008. Penderaan kanak-kanak : Cabaran, cegahan dan membantu, Kuala Lumpur: Penerbit Institut Sosial Malaysia, Kementerian Pembangunan Wanita, Keluarga Dan Masyarakat.

Konvensyen Hak Kanak-Kanak (CRC) \& Akta Kanak-Kanak 2001 Kurikulum Permata. 2008. Panduan pendidikan awal kanak-kanak 0-4 tahun, perak: Pusat penyelidikan perkembangan kanak-kanak negara, Universiti Pendidikan Sultan Idris.

Malaysia. 2005. Child Act 2001 (Act 611). Percetakan Nasional Malaysia Berhad. Mohd.

Muhd Dhamir Audi Azizul \& Samir Muhazzab Amin. 2019. Pendidikan kerja sosial di Malaysia: Satu penilaian kritikal. Jurnal Kemanusiaan, Penerbit UTM. Vol. 7(2): 20-26.

National Association of Social Workers. (2005). NASW standards for social work practice in child welfare. Washington, DC: NASW Press.

Noble (2007) Parent Choice of Early Childhood Education and Care Services Parental conceptions of quality in Greek early childhood education. European Early Childhood Education Research Journal, 22(1), 134-148

Nor Shafrin Ahmad \& Rohany Nasir. 2010. Emotional reactions and behavior of incest victims. Procedia Social and Behavioral Sciences. Vol. 5: 10231027.

Noor Zulaikha \& Ridzuan Hussin. 2006. Penilaian terhadap penderaan kanak kanak di malaysia: Satu kajian kes di enam buah negeri. Tanjung Malim: Universiti Pendidikan Sultan Idris.

Noremy Md. Akhir, Khadijah Alavi, Salina Nen, Fauziah Ibrahim, M. Suhaimi Mohamad \& Nazirah Hassan. 2012. Hubungan faktor dalaman penderaan 
fizikal terhadap kanak-kanak oleh ibubapa dlm Jurnal e-Bangi, vol. 7, no. $1, \mathrm{~ms} 1-14$.

Rahimah Abdul Aziz \& Suriati Iskandar. 2013. Working Children and Knowledge of Right to Education: A Study of Child Labour in Sabah, Malaysia. Asian Social Science; Vol. 9 (8): 23-33.

Rozilawati Hassan. 2003. Faktor-faktor pemilihan ibu bapa terhadap pusat jagaan kanak-kanak yang berkualiti. Latihan Ilmiah yang tidak diterbitkan. Pusat Pengajian Psikologi dan Pembangunan Manusia. Fakulti Sains Sosial dan Kemanusiaan, Universiti Kebangsaan Malaysia.

Salina Nen \& Jill Astbury. 2011. Organizational barriers in working with child sexual abuse (CSA) cases: The Malaysian Profesionals Experiences. Jurnal e-Bangi. Penerbit UKM. Vol. 6 (2): $255-272$.

Saparin, N. H. B. (2014). Malay Muslim Worldviews: Some thoughts for social work practice in Singapore. Journal of Religion \& Spirituality in Social Work: Social Thought, 33(1), 73-94.

Santrock, J. W. 2009. Life-span Development. Edisi ke-12. Boston: Mc-Graw Hills.
Summers, N. 2012. Fundamentals of case management practice: Skills for the human services (Fourth Edition ed.): Cengage Learning.

Spodek, B. \& Davis, M.D. 1982. A study of programs to prepare early childhood personnel. Journal of Teacher Education, 3(2), 42-44.

Syamsuddin, S., \& Azman, A. (2012). Memahami Dimensi Spiritualitas dalam Praktek Pekerjaan Sosial. Sosio Informa.

Tengku Fatimah Muliana Tengku Muda, \& Engku Ahmad Zaki Engku Alwi 2012. Care and protection against child abuse: with special reference to Malaysia Child Act 2001. Asian Social Science, 8(1), 202-208.

Woodside, M., \& McClam, T. 2012. Introduction to Human Services (7th ed.). Pacific

Grove, CA: Brooks Cole/Cengage.

Zaida Mustafa. 2017. Laporan Akhir Kajian Perkhidmatan Taman Asuhan Kanak-Kanak (Taska) di Malaysia. Jabatan Kebajikan Masyarakat dan Unitary International University. Kuala Lumpur. 
